\title{
Miskonsepsi Mahasiswa STKIP Rokania pada Materi Limit Fungsi
}

\author{
Jufri \\ Program Studi Pendidikan Teknologi Informasi, STKIP Rokania \\ Jl. Raya Pasir Pengaraian, Km 15 Langkitin, Rambah Samo, Kab. Rokan Hulu, Riau \\ jufrirokan@gmail.com
}

\begin{abstract}
This article discusses the misconceptions of STKIP Rokania students on the material limit of functions. Function limits are very important material for studying calculus, but what happens is that many students still have misconceptions about the material. The purpose of this study was to determine the level of misconceptions of students of Information Technology Education STKIP Rokania about the concept of function limits. The method used is descriptive qualitative method. That is research that utilizes qualitative data and is described descriptively. Descriptive qualitative research aims to describe, describe, explain, explain and answer in more detail the problems to be studied by studying as much as possible an individual, a group or an event. The research was conducted on the results of the student calculus test for the 2021/2022 academic year. The results showed that the misconceptions of Information Technology Education students about the concept of function limits belong to the moderate criteria, which is $33 \%$. Students who understand the concept are $45 \%$ and students who do not understand the concept are $22 \%$. The results of this study can be the basis for improving calculus learning in the future, for example, lecturers can use mathematical software to visualize the concept of limit functions.
\end{abstract}

Keywords: limit function, misconception

\begin{abstract}
Abstrak
Artikel ini membahas miskonsepsi mahasiswa STKIP Rokania pada materi limit fungsi. Limit fungsi merupakan materi yang sangat penting untuk mempelajari kalkulus, namun yang terjadi adalah banyak mahasiswa yang masih miskonsepsi terhadap materi tersebut. Tujuan penelitian ini adalah untuk mengetahui tingkat miskonsepsi mahasiswa Pendidikan Teknologi Informasi STKIP Rokania tentang konsep limit fungsi. Metode yang dilakukan adalah metode kualitatif deskiptif. Yaitu penelitian yang memanfaatkan data kualitatif dan dijabarkan secara deskrptif. Penelitian kualitatif deskriptif bertujuan untuk menggambarkan, melukiskan, menerangkan, menjelaskan dan menjawab secara lebih rinci permasalahan yang akan diteliti dengan mempelajari semaksimal mungkin seorang individu, suatu kelompok atau suatu kejadian. Penelitian dilakukan terhadap hasil tes kalkulus mahasiswa tahun akademik 2021/2022. Hasil penelitian menunjukkan bahwa miskonsepsi mahasiswa Pendidikan Teknologi Informasi tentang konsep limit fungsi tergolong pada kriteria sedang yaitu sebesar 33\%. Mahasiswa dengan paham konsep sebesar 45\% dan mahasiswa dengan tidak paham konsep sebesar $22 \%$. Hasil penelitian ini dapat menjadi dasar untuk perbaikan pembelajaran kalkulus dimasa akan dating, misalnya dosen dapat menggunakan software matematika untuk memvisualisasikan konsep limit fungsi.
\end{abstract}

Kata kunci: limit fungsi, miskonsepsi

Copyright (c) 2022 Jufri

$\triangle$ Corresponding author: Jufri

Email Address: jufrirokan@gmail.com (Jl. Raya Pasir Pengaraian, Km 15 Langkitin, Kab. Rokan Hulu, Riau)

Received 16 December 2021, Accepted 18 January 2022, Published 19 January 2022

\section{PENDAHULUAN}

Kalkulus merupakan mata kuliah wajib untuk mahasiswa matematika, matematika terapan, sains dan sains terapan. Demikian pula pada program studi sarjana Pendidikan Teknologi Informasi di STKIP Rokania, kalkulus disajikan pada semester 1. Pembelajaran kalkulus bertujuan untuk membekali mahasiswa dalam menganalis dan memecahkan masalah terutama masalah yang berkaitan dengan matematika terapan termasuk ilmu komputer. Materi dasar yang diajarkan pada kalkulus adalah limit fungsi. Limit fungsi sangat berperan penting dalam mempelajari kalkulus karena kalkulus 
adalah ilmu yang mempelajari tentang limit (Dale Varberg, 2006).

Objek langsung dalam matematika adalah fakta, keterampilan, konsep, dan aturan (Joordan, 2005). Suatu konsep dalam matematika disusun secara hierarkis, terstruktur, logis dan sistematis mulai dari konsep yang sederhana sampai dengan konsep yang kompleks. Pembelajaran matematika ibarat sebuah mata rantai yang saling berkesinambungan dan menjadikannya sebuah mata rantai yang utuh. Konsep-konsep yang saling terkait dalam matematika bahkan konsep sederhana memiliki peran sebagai prasyarat untuk konsep menuju memahami konsep yang paling kompleks (Lestari, 2012).

Pembelajaran materi limit akan berguna untuk pembelajaran materi selanjutnya yaitu turunan fungsi dan integral. Bahkan deret fungsi juga mengggunakan konsep limit. Sedangkan pada bidang ilmu komputer kalkulus digunakan untuk membuat Artificial Intelligence (Kecerdasan Buatan). Beberapa macam bidang yang menggunakan kecerdasan buatan antara lain sistem pakar, permainan komputer (games), logika fuzzy, jaringan syaraf tiruan dan robotika.

Pemanfaatan limit di bidang Ilmu Komputer untuk membuat kecerdasan buatan (Artificial Intelligence), dimana AI merupakan suatu percabangan dari teknik informatika yang dalam mempresentasikan pengetahuan lebih banyak menggunakan bentuk simbol-simbol daripada bilangan dan memproses informasi berdasarkan metode heuristic atau dengan berdasarkan sejumlah aturan.

Setiap individu memiliki konsep awal yang berbeda dalam memahami sesuatu. Demikian pula setiap mahasiswa juga memiliki konsepsi awal yang berbeda (Fitria, 2014). Tidak semua konsepsi yang dimiliki mahasiswa sesuai dengan konsepsi yang dimiliki oleh para ilmuwan. Konsepsi dikatakan salah jika konsepsi yang dimiliki mahasiswa tidak sama dengan konsepsi yang dimiliki ilmuan. Sehingga, mahasiswa dikatakan mengalami miskonsepsi, jika konsepsi yang dimiliki mahasiswa tidak sesuai dengan konsepsi para ilmuwan (Paul Suparno, 2013).

Miskonsepsi dapat berupa bawaan mahasiswa ketika masih di bangku sekolah dan terbawa hingga ke perguruan tinggi. Beberapa hasil riset menunjukkan bahwa miskonsepsi ditemukan dalam matakuliah kalkulus yaitu mengenai limit dan fungsi kontinu, diferensial integral dan kalkulus diferensial. Misalnya penelitian di SMA Negeri 1 Anjatan menunjukkan bahwa 1) Tingkat miskonsepsi yang dialami siswa termasuk dalam kategori rendah yaitu sebesar 12,18\%. Namun siswa yang kurang memahami konsep cukup tinggi yaitu sebesar 40,38\%, dan sisanya adalah siswa yang memahami konsep yaitu sebesar 47,44\%. (2) Miskonsepsi yang paling banyak dialami siswa terletak pada subkonsep yang menjelaskan makna fungsi limit pada suatu titik melalui perhitungan nilai di sekitar titik tersebut, yaitu sebesar 20,51\% (Winarso \& Toheri, 2017). Hasil penelitian di SMA Negeri 21 Medan (Purba \& Hutagaol, 2017) juga menunjukkan bahwa terjadi miskonsepsi siswa terhadap pemahaman materi limit fungsi. Selanjutnya penelitian yang dilakukan (Erdriani \& Devita, 2019) pada mahasiswa UPI YPTK Padang juga menunjukkan banyak terjadi miskonsepsi pemahaman mahasiswa terhadap materi limit fungsi.

Contoh miskonsepsi yang dilakukan oleh peserta didik adalah ketika peserta didik diminta 
untuk memberikan persepsinya terhadap simbol-simbol $\lim _{x \rightarrow c} f(x)=3$, dengan memberi mereka pertanyaan "apakah suatu fungsi harus didefinisikan pada titik itu untuk memiliki limit waktu dan apa hubungan antara nilai fungsi saat itu dengan konsep limit, maka dari beberapa peserta didik akan menjawab bahwa harus didefinisikan fungsi dalam c dan pasti nilai fungsi sama dengan 3" bertentangan dengan definisi dari batas (Larson \& Bruce Edwards, 2016).

Kemudian miskonsepsi juga ditemukan di bidang aljabar yaitu menentukan ruang vektor dari himpunan yang dilengkapi dengan dua operasi atau ruang vektor umum. Akibatnya, konsep ini menjadi salah satu konsep yang dianggap sulit oleh mahasiswa dan banyak mahasiswa yang mengalami miskonsepsi. Miskonsepsi biasanya berkembang seiring proses pembelajaran (Fitria, 2014).

Miskonsepsi matematis (Soedjaji, 2000) dapat terjadi dari beberapa sumber, (1) makna kata, seperti miskonsepsi tentang istilah "tinggi”, (2) aspek praktis, seperti nilai kemudian menganggap sama. Kepentingan $2 \times 5$ dan 5 x 2, (3) penyederhanaan, misalnya memahami barisan yang tidak berhubungan dengan fungsi atau pemetaan, (4) singularitas struktur matematika, misalnya ada anggapan dalam matematika tidak boleh ada kontradiksi tanpa melihat tinjauan dari sistem yang berbeda, (5) gambar, misalnya dengan menggambar himpunan bilangan asli sebagai himpunan bagian dari himpunan bilangan bulat yang menyimpulkan bilangan bulat lebih dari bilangan asli.

Miskonsepsi bermula dari siswa (prakonsepsi) yang sudah satu akan diteruskan dan dipertahankan. Keberhasilan setiap jenjang pendidikan mempengaruhi keberhasilan peserta didik menguasai kompetensi pada jenjang sebelumnya. Pemahaman yang baik akan menjadi dasar atau landasan yang baik untuk tingkat selanjutnya (Lorna Maxine Earl, 2014). Beberapa informasi menyebutkan bahwa rendahnya penguasaan konsep dan miskonsepsi pada siswa mempengaruhi rendahnya nilai Ketuntasan Minimum (KKM) pada konsep dan bidang studi.

Berdasarkan obsevasi terhadap hasil pekerjaan mahasiswa program studi Pendidikan Teknologi Informasi STKIP Rokania tahun 2021 terlihat bahwa 75\% mahasiswa masih banyak melakukan kesalahan-kesalahan konsep dalam menyelesaikan soal-soal terkait tentang limit fungsi. Misalnya mahasiswa tidak menuliskan lambang lim ketika menyelesaikan soal limit fungsi. Contoh kesalahan lainnya kebanyakan mahasiswa mempunyai pemahaman tanda $\infty$ pada hasil limit merupakan bilangan tak hingga, mestinya tanda $\infty$ pada hasil limit menunjukkan bahwa limit tidak terdefinisi pada titik yang ditunjuk. Kesalahan dalam pemahaman materi limit juga terjadi dalam memahami definisi limit fungsi baik secara aljabar maupun secara geometri. Sehingga solusi untuk masalah ini harus ditemukan agar tidak berlanjut dan berdampak pada materi selanjutya. Berdasarkan latar belakang yang telah diuraikan maka peneliti tertarik untuk menganalisis tingkat miskonsepsi yang dialami mahasiswa serta kecendrungan miskonsepsi mahasiswa pada materi limit fungsi. 


\section{METODE}

Penelitian yang dilakukan adalah penelitian kualitatif deskriptif. Penelitian kualitatif adalah jenis penelitian yang mengeksplorasi dan memahami makna di sejumlah individu atau sekelompok orang yang berasal dari masalah sosial (John W. Creswell, 2012). Penelitian dilaksanakan pada bulan September 2021 dengan subjek penelitian 26 mahasiswa Pendidikan Teknologi Informasi STKIP Rokania tahun akademik 2021/2022.

Desain yang digunakan dalam penelitian ini adalah penelitian kualitatif deskriptif yang menggambarkan suatu peristiwa di masa sekarang. Penelitian kualitatif deskriptif ini bertujuan untuk mendeskripsikan, merangkum berbagai kondisi, situasi atau fenomena yang berbeda yang ada di masyarakat yang menjadi objek penelitian (Bowen, 2009).

Miles dan Huberman (Sugiyono, 2013) mengemukakan bahwa: "Aktivitas dalam analisis data kualitatif terdiri atas tiga tahap: a) Data reduction, b) Data display dan c) Conclusion drawing/ verification". Sebagai acuan pengelompokan derajat tingkatan miskonsepsi dapat dilihat pada Tabel 1. Sedangkan sebagai acuan untuk kategori miskonsepsi dapat dilihat pada Tabel 2.

Tabel 1. Kelompok tingkat ujicoba konsep

\begin{tabular}{|c|c|c|}
\hline Kriteria & Derajat Pemahaman & Kategori \\
\hline $\begin{array}{l}\text { - Tidak ada jabawan } \\
\text { - Mengulangi pernyataan, tetapi jawabannya tidak } \\
\text { ada hubungannya dengan pertanyaan atau tidak } \\
\text { jelas } \\
\text { - Dijawab dengan dengan penjelasan tidak logis } \\
\text { - Jawaban tidak menunjukkan konsep terkontrol } \\
\text { tetapi tidak ada pernyataan dalam jawaban yang } \\
\text { menunjukkan miskonsepsi } \\
\text { - Jawaban hanya menunjukkan sebagian konsep } \\
\text { yang dikuasai tanpa ada miskonsepsi } \\
\text { - Jawaban menunjukkan konsep yang dipahami } \\
\text { oleh semua penjelasan yang benar }\end{array}$ & $\begin{array}{l}\text { Miskonsepsi } \\
\text { Mengerti sebagian dengan } \\
\text { kesalahpahaman } \\
\text { Mengerti sebagian } \\
\text { Memahami konsep }\end{array}$ & Tidak paham \\
\hline
\end{tabular}

Tabel 2. Kategori Miskonsepsi (Saheb, W. A., Supriadi, B., \& Prihandono, 2018)

\begin{tabular}{|c|c|}
\hline Persentase (\%) & Kategori \\
\hline $0-30$ & Rendah \\
$31-60$ & Sedang \\
$61-100$ & Tinggi \\
\hline
\end{tabular}

\section{HASIL DAN DISKUSI}

Berdasarkan hasil penelitian didapat bahwa mahasiswa yang mengalami Miskonsepsi jumlahnya lebih sedikit dibandingkan dengan mahasiswa dengan kategori Paham Konsep dan lebih banyak dibandingkan dengan mahasiswa dengan kategori Tidak Paham Konsep. Ini berarti mahasiswa yang mengalami miskonsepsi pada materi limit fungsi tergolong sedang yakni sebesar 33\%. Sedangkan mahasiswa yang paham konsep secara keseluruhan $45 \%$ dan yang tidak paham konsep 
$22 \%$. Secara keseluruhan data tentang mahasiswa yang mengalami miskonsepsi mahasiswa pada materi limit fungsi dapat dilihat pada Tabel 3. Distribusi dari kelima subkonsep tesebut adalah sebagai berikut.

Pertama, bagian konsep mamahami definisi limit fungsi. Mahasiswa yang mengalami miskonsepsi sebesar 28\%, mahasiswa yang memahami konsep sebesar 50\% dan mahasiswa yang tidak paham konsep sebesar $22 \%$. Salah satu jawaban mahasiswa terkait soal definisi limit dapat dilihat pada Gambar 1 .
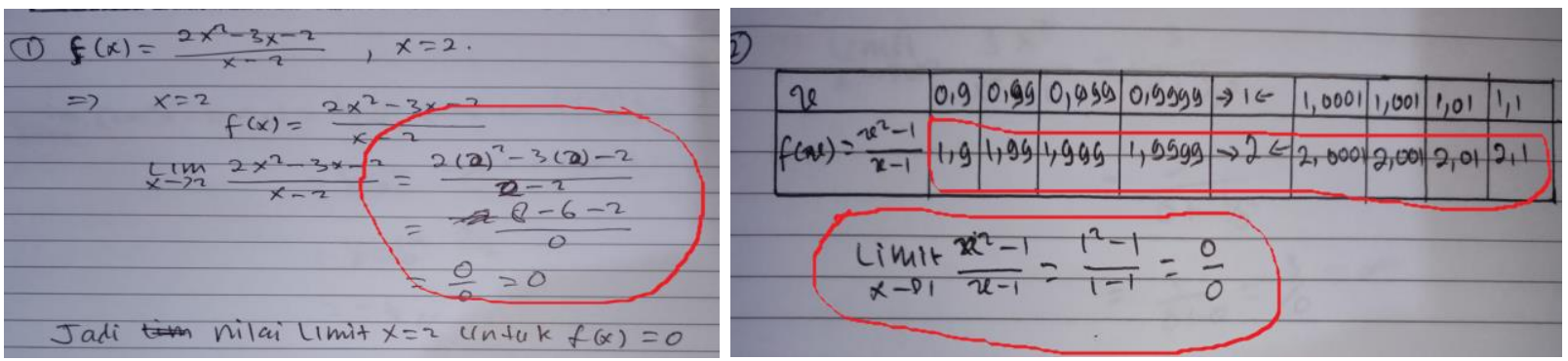

Gambar 1. Jawaban mahasiswa terkait soal definisi limit fungsi

Kedua, pada bagian konsep menggunakan teorema limit mahasiswa yang mengalami miskonsepsi sebesar 19\%, mahasiswa yang paham konsep sebesar 68\% dan mahasiswa yang tidak paham konsep sebesar 13\%. Jawaban siswa terkait penggunaan teorema limit dapat dilihat pada Gambar 2.

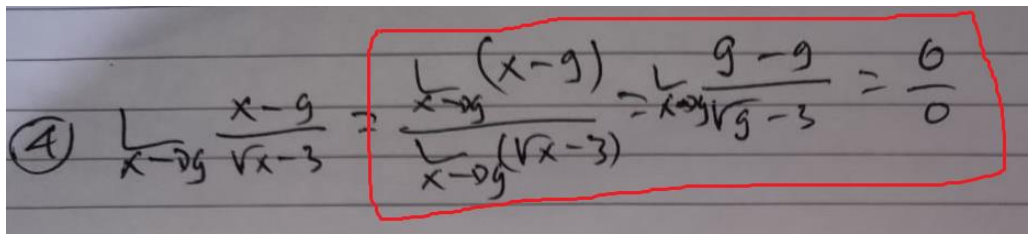

Gambar 2. Jawaban siswa terkait pengunaan teorema limit

Ketiga, pada bagian konsep limit melibatkan fungsi trigonometri mahasiswa yang mengalami miskonsepsi sebesar 30,5\%, mahasiswa yang paham konsep $40 \%$ dan yang tidak paham konsep $29,5 \%$. Salah satu jawaban mahasiswa terkait soal limit fungsi d=yang melibatkan fungsi trigonometri dapat dilihat pada Gambar 3.

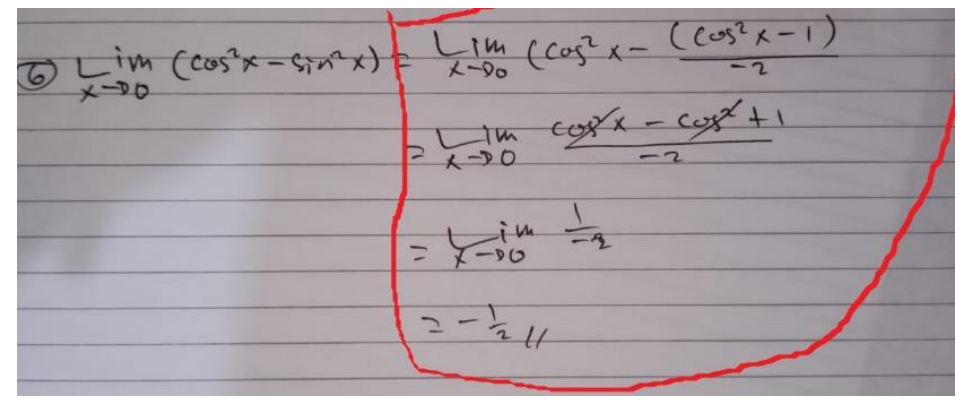

Gambar 3. Jawaban siswa terkait soal limit fungsi yang melibatkan fungsi trigonometri

Keempat, pada bagian konsep limit di tak hingga dan limit tak berhingga mahasiswa yang 
mengalami miskonsepsi sebasar 54,5\%, mahasiswa yang paham konsep sebesar 20,5\% dan mahasiswa yang tidak paham konsep sebesar $25 \%$. Jawaban siswa terkait soal limit di tak hingga dan limit tak berhingga dapat dilihat pada Gambar 4.

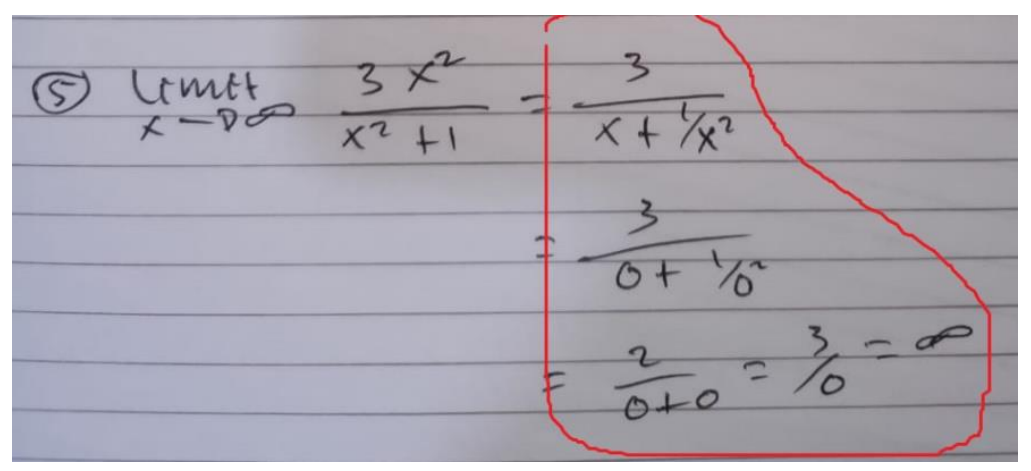

Gambar 4. Jawaban siswa terkait soal limit di tak hingga dan limit tak berhingga

Kelima, pada bagian konsep kontuinitas fungsi mahasiswa yang mengalami miskonsepsi sebesar 32\%, mahasiswa yang paham konsep sebesar 47,5\% dan mahasiswa yang tidak paham konsep sebesar 20,5\%. Jawaban mahasiswa terkait soal kokontinuan fungsi dapat dilihat pada Gambar 5.

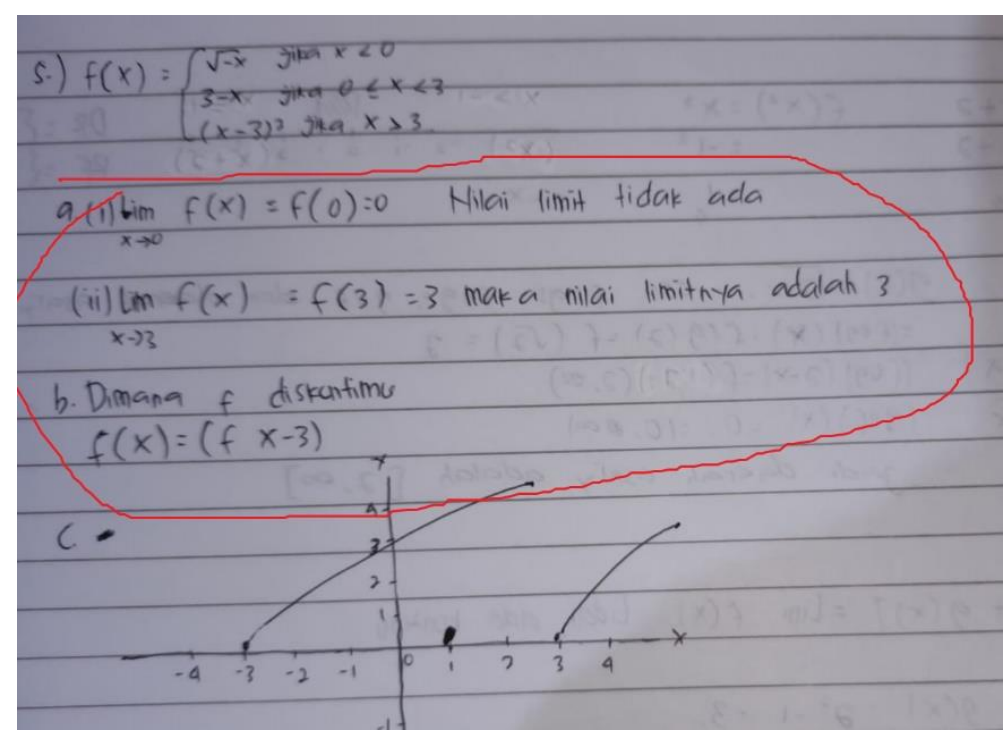

Gambar 5. Jawaban mahasiswa terkait soal kokontinuan fungsi.

Bagian miskonsepsi terbesar terjadi pada bagian konsep limit di takhingga dan limit tak berhingga, yaitu sebesar 54,5\%. Hal ini terjadi kerena mahasiswa kesulitan membedakan antara limit di tak hingga yaitu limit ketika $x \rightarrow \infty$ dan limit tak hingga yaitu $\lim _{x \rightarrow c^{+}} f(x)=\infty$. Mahasiswa yang mengalami miskonsepsi meyakini bahwa $\lim _{x \rightarrow c^{+}} f(x)=\infty$ adalah memaparkan cara khusus dalam hal limit tidak ada. Padahal $\infty$ maksudnya adalah "ada dalam pengertian tak-hingga" untuk memaparkan limit-limit yang demikian (Dale Varberg, 2006).

Tabel 3. Persentase mahasiswa paham konsep, Miskonseosi dan Tidak paham konsep 


\begin{tabular}{|c|c|c|c|c|}
\hline \multirow{2}{*}{ Bagian Konsep } & \multirow{2}{*}{ Pertanyaan } & \multicolumn{3}{|c|}{ Kategori Jawaban Mahasiswa } \\
\hline & & PK* & MK** & TPK*** \\
\hline \multirow[t]{3}{*}{ Memahami definisi limit } & 1 & $47 \%$ & $31 \%$ & $22 \%$ \\
\hline & 2 & $53 \%$ & $25 \%$ & $22 \%$ \\
\hline & $\bar{x}$ & $50 \%$ & $28 \%$ & $22 \%$ \\
\hline \multirow[t]{3}{*}{ Menggunakan teorema limit } & 3 & $64 \%$ & $22 \%$ & $14 \%$ \\
\hline & 4 & $72 \%$ & $17 \%$ & $11 \%$ \\
\hline & $\overline{\boldsymbol{x}}$ & $68 \%$ & $19 \%$ & $13 \%$ \\
\hline \multirow[t]{3}{*}{ Limit melibatkan fungsi trinonometri } & 5 & $22 \%$ & $36 \%$ & $42 \%$ \\
\hline & 6 & $58 \%$ & $25 \%$ & $17 \%$ \\
\hline & $\bar{x}$ & $40 \%$ & 30,5\% & 29,5 \\
\hline \multirow[t]{3}{*}{ Limit di tak hingga dan limit tak berhingga } & 7 & $19 \%$ & $56 \%$ & $25 \%$ \\
\hline & 8 & $22 \%$ & $53 \%$ & $25 \%$ \\
\hline & $\bar{x}$ & $20,5 \%$ & $54,5 \%$ & $25 \%$ \\
\hline \multirow[t]{3}{*}{ Kontuinitas fungsi } & 9 & $53 \%$ & $25 \%$ & $22 \%$ \\
\hline & 10 & $42 \%$ & $39 \%$ & $19 \%$ \\
\hline & $\bar{x}$ & $47,5 \%$ & $32 \%$ & $20,5 \%$ \\
\hline \multicolumn{2}{|l|}{ Rata-rata Total } & $45 \%$ & $33 \%$ & $22 \%$ \\
\hline
\end{tabular}

Keterangan: $* \mathrm{PK}=$ Paham Konsep, ${ }^{* * \mathrm{MK}}=$ Mis Konsepsei, $* * * \mathrm{TPK}=$ Tidak Paham Konsep

Beberapa analisis berikut dapat dijadikan kemungkinan penyebab terjadinya miskonsepsi mahasiswa pada materi limit fungsi.

1. Miskonsepsi kesalahan mahasiswa tidak menuliskan lambang "limit" saat melakukan prosedur hitungan. Mahasiwa juga melakukan kesalahan memahami konsep ada tidaknya limit ketika hasilnya 0 (Abidin, 2012). Kemungkinan penyebab miskonsepsi tersebut adalah kurangnya pemahaman tentang definisi konsep limit fungsi dan kurangnya pemahaman tentang nilai dan tempat (Lerner, 2003). Kesalahan terjadi hampir pada setiap jawaban siswa seperti pada Gambar 1, Gambar 2 dan Gambar 3.

2. Miskonsepsi mahasiswa dalam menyelesaikan limit trigonometri terjadi karena mahasiswa tidak menguasai konsep trigonometri, misalnya masalah penyederhanaan bentuk trigonometri. Ini terjadi seperti diperlihatkan pada Gambar 3.

3. Kesalahan saat melakukan prosedur hitung limit dan salah hitung sehingga siswa melakukan kesalahan operasi aritmatika memfaktorkan fungsi aljabar untuk mendapatkan hasil tersebut (Abidin, 2012). Miskonsepsi ini dapat dilihat pada Gambar 1, Gambar 2, Gambar 3 dan Gambar 4.

4. Kemungkinan penyebab miskonsepsi adalah kurangnya pemahaman tentang nilai dan tempat, serta kesalahan perhitungan (Lerner, 2003). Temuan pada hasil jabawaban mahasiswa yaitu mahasiswa tidak memecahkan soal dengan sistematis. Kemudian mahasiswa cenderung menyelelesaikan soal menggunakan tanda "=" langsung disambung ke kanan dibandingkan ke bawah. Dapat dilihat pada Gambar 2. 
5. Faktor dosen dalam mengajar matematika. Tidak sedikit dosen yang kurang memperhatikan pencapaian pemahaman mahasiswa terhadap penguasaan konsep limit. Sehingga mahasiswa dapat mengalami miskonsepsi. Kemungkinan penyebab miskonsepsi adalah kurangnya penekanan dosen pada teorema fungsi limit dan kurangnya pemahaman konsep tentang keberadaan limit fungsi dan hubungannya dengan limit kiri dan kanan (Joordan, 2005). Untuk mengatasi permasalahan ini dosen dapat melakukan terobosan-terobosan dalam mengajarkan konsep limit fungsi. Misalkan dengan menggunakan software matematika seperti Geogebra dan Maple. Selain itu dosen juga dapat memberikan materi tambahan atau memberikan informasi tambahan kepada mahasiswa terkait konsep-konsep dasar matematika. Misalnya pemahaman tentang pembagian

dengan $0, \frac{0}{0}=$ tidak terdefinisi, $\frac{a}{0}=$ tidak terdefinisi, dan $\frac{0}{a}=0$ serta konsep-konsep dasar lainnya.

\section{KESIMPULAN}

Berdasarkan hasil penelitian dapat disimpulkan bahwa tingkat miskonsepsi mahasiswa Pendidikan Teknologi Informasi STKIP Rokania tahun akademik 2021/2022 termasuk pada kategori sedang yakni sebesar 33\%. Mahasiswa kategori paham konsep sebesar 45\% dan mahasiswa tidak paham konsep sebesar 22\%. Miskonsepsi ini terjadi dengan berbagai faktor yakni faktor internal dan faktor eksternal. Faktor internal terjadi karena mahasiswa kurang pemahaman konsep-konsep matematika dasar dan kurang teliti dalam menyelesaikan soal. Faktor eksternal yakni kurangnya penekanan konsep dari dosen yang mengajar. Untuk mengatasi ini mahasiswa dapat mengulang materi-materi SMA yang berkaitan dengan limit fungsi serta sering melakukan latihan menyelesaikan soal tentang limit fungsi. Dimasa mendatang juga dapat dilakukan pembelajaran dengan menggunakan software matematika guna mendukung dan melakukan penguatan konsep limit fungsi.

\section{UCAPAN TERIMA KASIH}

Ucapan terima kasih kepada ketua STKIP Rokania dan semua civitas yang mendukung penelitian ini. Terima kasih juga kepada ketua Program Studi Pendidikan Teknologi Informasi STKIP Rokania yang telah memfasilitasi sehingga penelitian ini terlaksana dengan baik.

\section{REFERENSI}

Abidin, Z. (2012). Aanlisi Kesalahan Mahasiswa Prodi Pendidikan Matematika Fakultas Tarbiyah IAIN Ar-Raniry Dalam Mata Kuliah Trigonometri dan Kalkulus 1. Jurnal Ilmiah Didaktika, 13(1). https://doi.org/10.22373/jid.v13i1.472

Bowen, G. A. (2009). Document analysis as a qualitative research method. In Qualitative Research Journal (Vol. 9, Issue 2). https://doi.org/10.3316/QRJ0902027

Dale Varberg, E. P. and S. R. (2006). Calculus (9th ed.). Prentice Hall. 
Erdriani, D., \& Devita, D. (2019). Analisis Kesulitan Mahasiswa dalam Menyelesaikan Soal pada Materi Pertidaksamaan dan Fungsi Limit. Edumatika: Jurnal Riset Pendidikan Matematika, 2(1), 52. https://doi.org/10.32939/ejrpm.v2i1.330

Fitria, A. (2014). Miskonsepsi Mahasiswa Dalam Menentujan GRUP Pada Struktur Aljabar Menggunakan Certainty of Response Index (CRI) di Jurusan Pendidikan Matematika IAIN Antasari. JPM IAIN Antasari, 1(2), 35-43.

John W. Creswell. (2012). Educational research: planning, conducting, and evaluating quantitative and qualitative research 4th ed. Prentice Hall Upper Saddle River, NJ.

Joordan, T. (2005). Misconceptions of the limit concept in Mathematics course for Engineering Students. Master The(February).

Larson, R., \& Bruce Edwards. (2016). Calculus with CalcChat an CalcView.

Lerner, J. (2003). Learning disabilities: Theories, diagnosis, and teaching practices. Houghton Mifflin Company.

Lestari, D. P. (2012). Deskripsi kesulitan belajar pada operasi penjumlahan dengan teknik menyimpan siswa kelas I SD N 3 Panjer Kecamatan Kebumen tahun ajaran 2011/2012. Kalam Cendekia PGSD Kebumen, 2(1).

Lorna Maxine Earl. (2014). Assessment as learning: Using classroom assessment to maximize student learning. Hawker Brownlow Education.

Paul Suparno. (2013). Miskonsepsi dan perubahan konsep dalam pendidikan fisika (1st ed.). PT Gramedia Widiasarana Indonesia.

Purba, S., \& Hutagaol, Y. E. (2017). Analisis Kesalahan Konsep Siswa Terhadap Materi Limit Fungsi Di Kelas XI MIA 3 SMA Negeri 21 Medan. Jurnal Pendidikan Matematika Dan Sains, 12(2), 90-99.

Saheb, W. A., Supriadi, B., \& Prihandono, T. (2018). Implementasi pendidikan karakter dan IPTEK untuk generasi milineal Indonesia dalam menuju Sustainable Development Goals (SDGs) 2030. Prosiding Seminar Pendidikan, 6-13.

Soedjaji, R. (2000). Kiat Pendidikan Matematika di Indonesia,(Cet. 1). Direktorat Jenderal Pendidikan Tinggi Departemen Pendidikan Nasional.

Sugiyono, P. D. (2013). Metode Penelitian Kuantitatif, Kualitatif dan R \&. D. Penerbit Alfabeta.

Winarso, W., \& Toheri, T. (2017). A case study of misconceptions students in the learning of mathematics; The concept limit function in high school. Jurnal Riset Pendidikan Matematika, 4(1), 120. https://doi.org/10.21831/jrpm.v4i1.12060. 